\title{
Responses of Sweet Basil to Different Daily Light Integrals in Photosynthesis, Morphology, Yield, and Nutritional Quality
}

\author{
Haijie Dou \\ Department of Horticultural Sciences, Texas A\&M University, College \\ Station, TX 77843
}

Genhua Niu'

Department of Horticultural Sciences, Texas A\&M AgriLife Research Center at El Paso, Texas A\&M University System, 1380 A\&M Circle, El Paso, TX 79927

\section{Mengmeng Gu \\ Department of Horticultural Sciences, Texas A\&M AgriLife Extension Service, College Station, TX 77843}

\section{Joseph G. Masabni \\ Department of Horticultural Sciences, Texas A\&M AgriLife Research and Extension Center, Texas A\&M University System, 1710 FM 3053 N, Overton, TX 75684}

Additional index words. Gas exchange rate, $\mathrm{Chl} \mathrm{a} / \mathrm{b}$, indoor controlled environment, artificial lighting, phenolics, antioxidant capacity

\begin{abstract}
Consumption of basil (Ocimum basilicum) has been increasing worldwide in recent years because of its unique aromatic flavor and relatively high concentration of phenolics. To achieve a stable and reliable supply of basil, more growers are turning to indoor controlled-environment production with artificial lighting due to its high environmental controllability and sustainability. However, electricity cost for lighting is a major limiting factor to the commercial application of indoor vertical farming, and little information is available on the minimum light requirement to produce uniform and high-quality sweet basil. To determine the optimal daily light integral (DLI) for sweet basil production in indoor vertical farming, this study investigated the effects of five DLIs, namely, $9.3,11.5,12.9,16.5$, and $17.8 \mathrm{~mol} \cdot \mathrm{m}^{-2} \cdot \mathrm{d}^{-1}$ on basil growth and quality. 'Improved Genovese Compact' sweet basil was treated with five DLIs provided by white fluorescent lamps (FLs) for $21 \mathrm{~d}$ after germination, and gas exchange rate, growth, yield, and nutritional quality of basil plants were measured to evaluate the effects of the different DLIs on basil growth and quality. Results indicated that basil plants grown under higher DLIs of $12.9,16.5$, or $17.8 \mathrm{~mol} \cdot \mathrm{m}^{-2} \cdot \mathrm{d}^{-1}$ had higher net photosynthesis, transpiration, and stomatal conductance $\left(g_{S}\right)$, compared with those under lower DLIs of 9.3 and $11.5 \mathrm{~mol} \cdot \mathrm{m}^{-2} \cdot \mathrm{d}^{-1}$. High DLIs resulted in lower chlorophyll (Chl) $\mathbf{a}+\mathbf{b}$ concentration per leaf fresh weight $(\mathrm{FW})$, higher $\mathrm{Chl}$ a/b ratios, and larger and thicker leaves of basil plants. The shoot FW under DLIs of $12.9,16.5$, and $17.8 \mathrm{~mol} \cdot \mathrm{m}^{-2} \cdot \mathrm{d}^{-1}$ was $54.2 \%, 78.6 \%$, and $77.9 \%$, respectively, higher than that at aLI of $9.3 \mathrm{~mol} \cdot \mathrm{m}^{-2} \cdot \mathrm{d}^{-1}$. In addition, higher DLIs led to higher soluble sugar percent and dry matter percent than lower DLIs. The amounts of total anthocyanin, phenolics, and flavonoids per plant of sweet basil were also positively correlated to DLIs, and antioxidant capacity at a DLI of $17.8 \mathrm{~mol} \cdot \mathrm{m}^{-2} \cdot \mathrm{d}^{-1}$ was $73 \%$ higher than that at a DLI of $9.3 \mathrm{~mol} \cdot \mathrm{m}^{-2} \cdot \mathrm{d}^{-1}$. Combining the results of growth, yield, and nutritional quality of sweet basil, we suggest a DLI of 12.9 $\mathbf{m o l} \cdot \mathrm{m}^{-2} \cdot \mathrm{d}^{-1}$ for sweet basil commercial production in indoor vertical farming to minimize the energy cost while maintaining a high yield and nutritional quality.
\end{abstract}

Sweet basil ( $O$. basilicum) is often referred as the "king of herbs" or the "royal herb" and is widely used in cooking and medicinal practices, as well as a fragrant, ornamental plant for gardens and containers because of its unique flavor and relatively high content of phenolic compounds (Chiang et al., 2005; Kruma et al., 2008; Makri and Kintzios, 2008). The United States is both the largest producer and importer of basil in the world, with most of its production in open fields (DAFF, 2012). However, the yield and quality of essential oils and phenolics of basil grown outdoors is hard to control and its phytochemical concentration varies widely with cultivation location, season, and cultivar (Fischer et al., 2011; Hassanpouraghdam et al., 2010; Pushpangadan and George,
2012). To achieve a stable and reliable supply of basil, more growers are turning to indoor controlled-environment production, which has proven to be a suitable alternative to open field and greenhouse production (Liaros et al., 2016; Saha et al., 2016).

Indoor vertical farming, also known as "plant factory," is a highly controlled environmental system for plant production that uses multiple-layer culture shelves with artificial lighting (Despommier, 2010; Kozai et al., 2015). In consideration of global climate change and increasing urban populations, food security is an increasingly pressing matter, especially considering limited resources such as arable land, clean water, and fuel energy (Dunwoody, 2014; Liaros et al., 2016). Indoor vertical farming emerged as an environmentally sustainable form of plant production because of its high resourceuse efficiency of both land and water (Despommier, 2013; Kozai, 2013; Kozai et al., 2015; Touliatos et al., 2016). The utilization efficiency of land, water, $\mathrm{CO}_{2}$, and light energy in indoor vertical farming were $100,40,2$, and 1.7 times of those in greenhouses, respectively (Kozai, 2007; Ohyama et al., 2003; Yokoi et al., 2005). In recent years, the number of indoor vertical farming facilities has increased rapidly in Japan, China, and other Asian countries (Kozai et al., 2015). In North America, vertical farming has been built for commercial production of leafy greens, herbs, and transplants (Kozai et al., 2015). For example, AeroFarms, an enterprise specializing on indoor farming, built its ninth farm in Newark, NJ, and is the world's largest indoor vertical farm based on annual output (AeroFarms, 2017). As one of the most popular herbs in the United States, sweet basil is a great candidate plant for indoor vertical farming because of its high value and demand (Liaros et al., 2016).

Light is one of the most important environmental factors that affects plant development and regulates plant behavior depending on light quantity, quality, direction, and duration (Chang et al., 2008; Dou et al., 2017; Figueiredo et al., 2008; ShafieeHajiabad et al., 2016). Daily light integral [the product of photosynthetic photon flux density (PPFD) and photoperiod] represents the total $P P F$ radiated by a light source in $24 \mathrm{~h}$ and usually has a linear relationship with crop yield and nutrient accumulation (Bochenek and Fallstrom, 2016; Colonna et al., 2016; Dai et al., 2009). Basil originates in tropical and subtropical regions and is adapted to moderately high PPFD and longday irradiation (Pushpangadan and George, 2012). However, artificial lighting accounts for $\approx 80 \%$ of total electricity consumption in an indoor vertical farm, which makes energy conservation one of the biggest concerns for its commercial application (Ohyama et al., 2002). DLIs of $12-17 \mathrm{~mol} \cdot \mathrm{m}^{-2} \cdot \mathrm{d}^{-1}$ are recommended for vegetables and herbs in vertical farming in terms of energy savings (Albright et al., 2000; Kozai et al., 2015). A few studies explored the effects of DLIs from 
13.5 to $34.6 \mathrm{~mol} \cdot \mathrm{m}^{-2} \cdot \mathrm{d}^{-1}$ on basil growth and development (Beaman et al., 2009; Chang et al., 2008), but no study has determined the optimum DLI between 12 and $17 \mathrm{~mol} \cdot \mathrm{m}^{-2} \cdot \mathrm{d}^{-1}$ for sweet basil production under indoor controlled environment. Between DLIs of 17.3 and $23.0 \mathrm{~mol} \cdot \mathrm{m}^{-2} \cdot \mathrm{d}^{-1}$, no differences in plant height, canopy diameter, or shoot yield among 'Genovese', 'Italian Large Leaf', and 'Nufar' basil were observed, which were lower than the basil grown under DLIs of 28.8 and $34.6 \mathrm{~mol} \cdot \mathrm{m}^{-2} \cdot \mathrm{d}^{-1}$ in a growth chamber, respectively (Beaman et al., 2009). In a glasshouse condition, there was no difference in photosynthesis of 'Genovese' basil between DLIs of $13.5 \mathrm{~mol} \cdot \mathrm{m}^{-2} \cdot \mathrm{d}^{-1}$ (light shading in a glasshouse) and $24.9 \mathrm{~mol} \cdot \mathrm{m}^{-2} \cdot \mathrm{d}^{-1}$ (full sunlight), whereas a DLI of $5.3 \mathrm{~mol} \cdot \mathrm{m}^{-2} \cdot \mathrm{d}^{-1}$ (heavy shading) significantly reduced the photosynthetic rate, leaf area per plant, shoot FW per plant, and total essential oils concentration (Chang et al., 2008). The total amount of essential oil of basil 'Bageco' increased significantly with supplemental radiation provided by high-pressure sodium-vapor lamp compared with plants grown under sunlight (Nitz and Schnitzler, 2004). Based on these circumstances, the objective of this article was to determine the minimum DLI for sweet basil production with comparable nutritional values in indoor vertical farming.

\section{Materials and Methods}

Plant materials and culture. The experiment was conducted in a large walk-in growth room with multiple "book-shelf stands" each with four vertical layers spaced $25 \mathrm{~cm}$ apart at the Texas AgriLife Research and Extension Center at El Paso, TX, from 7 Mar. to 26 Apr. 2017 and repeated from 17 Apr. to 29 May. 'Improved Genovese Compact' sweet basil (Johnny's Selected Seeds, Winslow, ME) was used in both experiments. For both experiments, one basil seed per cell was sown in 72 square cell trays (length $3.86 \mathrm{~cm}$, height $5.72 \mathrm{~cm}$, and volume $59 \mathrm{~mL}$ ) with all-purpose commercial mix Metro-Mix 360 (Sun Gro ${ }^{\circledR}$ Horticulture, Bellevue, WA). All trays were put under mist in a greenhouse for germination. The seedlings were moved out from mist after germination and grown in a greenhouse for 2 weeks. The seedlings were then transplanted to 4 " square pots (length $9.52 \mathrm{~cm}$, height $8.26 \mathrm{~cm}$, and volume $574 \mathrm{~mL}$ ) with Metro-Mix 360 when roots were visible on the outside of the plug

Received for publication 14 Dec. 2017. Accepted for publication $23 \mathrm{Feb} .2018$.

This research is supported partially by the USDA National Institute of Food and Agriculture Hatch project TEX090450 and Texas A\&M AgriLife Research.

We appreciate the assistance from Youping Sun, Christina Perez, Triston Hooks, and the student workers at the Texas A\&M AgriLife Research Center at El Paso, TX.

${ }^{1}$ Corresponding author. E-mail: gniu@ag.tamu. edu. root ball, and uniform plants were selected and moved to the walk-in growth room for different DLI treatments for $21 \mathrm{~d}$.

Treatments. The experiment was conducted as a completely randomized design with a single factor (DLI) at five levels, 9.3, 11.5, $12.9,16.5$, and $17.8 \mathrm{~mol} \cdot \mathrm{m}^{-2} \cdot \mathrm{d}^{-1}$ (hereafter, DLI 9.3, DLI 11.5, DLI 12.9, DLI 16.5, and DLI 17.8, respectively), created by growing basil plants under five different PPFD of 160 , $200,224,290$, or $310 \mu \mathrm{mol} \cdot \mathrm{m}^{-2} \cdot \mathrm{s}^{-1}$, respectively, with the same 16-h photoperiod provided by Cool White Alto Linear FLs (Philips Lighting, Somerset, NJ). All treatments were randomly arranged in the growth room and 18 uniform plants were randomly assigned for each treatment (replications). For each growing layer (treatment), mechanical mini fans (LS1225A-X; AC Infinity, City of Industry, CA), temperature sensor, and reflective aluminum sheets were installed to keep a uniform growing environment among treatments. To minimize light distribution being disproportionate within each treatment, all plants were systematically rearranged every $3 \mathrm{~d}$. The PPFD in each treatment was measured at $15 \mathrm{~cm}$ from FLs at nine points using PS-100 spectroradiometer (Apogee Instruments, Logan, UT). All plants were subirrigated with a nutrient solution containing 1.85 g. $\mathrm{L}^{-1}(277.5 \mathrm{ppm} \mathrm{N}) 15 \mathrm{~N}-2.2 \mathrm{P}-12.5 \mathrm{~K}$ (Peters 15-5-15 Ca-Mg Special; The Scotts Company, Marysville, OH) according to plants' water requirement, maintaining an electrical conductivity of $2.0 \mathrm{dS} \cdot \mathrm{m}^{-1}$ and a $\mathrm{pH}$ of 6.0 as recommended (Kiferle et al., 2011; Park et al., 2016; Sgherri et al., 2010; Walters and Currey, 2015). Plant canopy temperatures in each treatment were recorded and maintained at $24.5^{\circ} \mathrm{C} / 21.3^{\circ} \mathrm{C}$ day/night. The basil plants in the first experiment were transplanted $3 \mathrm{~d}$ later than the plants in the second experiment and basil plants that had a higher yield in the first experiment when harvest; however, both experiments showed a similar trend, so only data from the second experiment are presented.

Growth characteristics. The growth characteristics such as plant height, two perpendicular widths, and the number of internodes were recorded on day 1 (D1) of the treatment and then weekly. Six plants per treatment were randomly selected for measurement. Height and two perpendicular widths of the first branch of basil plants were measured on D21, the end of the experiment. Leaf area per plant was measured using a leaf area meter (LI-3100; LI-COR, Lincoln, NE), and shoot and root FW per plant were recorded on D21. The shoot and root tissues were dried at $80^{\circ} \mathrm{C}$ in a drying oven (Grieve, Round Lake, IL) for $3 \mathrm{~d}$ to determine the dry weight (DW) per plant.

Gas exchange and Chl concentration analysis. A portable gas exchange analyzer (CIRAS-3; PP Systems International, Amesbury, MA) was used to measure the gas exchange rate of basil leaves on D20. A PLC3 leaf cuvette with an LED light unit was used, and PPFD, relative air humidity, and $\mathrm{CO}_{2}$ concentration inside the leaf chamber were kept constant at $800 \mu \mathrm{mol} \cdot \mathrm{m}^{-2} \cdot \mathrm{s}^{-1}, 50 \%$, and 390 $\mu \mathrm{mol} \cdot \mathrm{mol}^{-1}$, respectively. The soil plant analysis development (SPAD) index of basil was recorded weekly to quantify relative $\mathrm{Chl}$ concentration per leaf area in basil leaves using a Chl meter SPAD-502 (KonicaMinolta cooperation, Ltd., Osaka, Japan). On D21, $\approx 0.2 \mathrm{~g}$ of basil leaves were cut into small pieces and then extracted in $80 \%$ methanol $(\mathrm{v} / \mathrm{v})$ for $3 \mathrm{~d}$. The absorbance of extracts was measured at 663 and $645 \mathrm{~nm}$ using a spectrophotometer (Genesys 10S ultraviolet/Vis; Thermo Fisher Scientific, Madison, WI), and the concentrations of Chl a and Chl b were calculated according to Porra et al. (1989) and were used to calculate $\mathrm{Chl} \mathrm{a}+\mathrm{b}$ concentration and $\mathrm{Chl}$ $\mathrm{a} / \mathrm{b}$ ratio.

Nutritional quality measurement. Six plants per treatment were randomly selected for measurements of soluble sugar percent $(\%)$, anthocyanin concentration, total phenolic concentration, total flavonoid concentration, and antioxidant capacity of basil leaves on D21 to evaluate the effects of DLIs on basil nutritional quality. The soluble sugar percent of fresh basil leaves was measured using a Brix refractometer (Extech Instruments, Nashua, NH). Fresh basil leaves were collected and stored in a deep freezer at $-80{ }^{\circ} \mathrm{C}$ (IU1786A; Thermo Fisher Scientific, Marietta, $\mathrm{OH}$ ) until phytochemical analysis. About $2 \mathrm{~g}$ of fresh basil leaves were ground in liquid nitrogen and extracted with $15 \mathrm{~mL} 1 \%$ acidified methanol in darkness. After overnight extraction, the mixture was centrifuged at 13,200 rpm for $15 \mathrm{~min}$ and the supernatant was collected for analysis. The absorbance of extracts was measured at $530 \mathrm{~nm}$ using a spectrophotometer mentioned previously and the anthocyanin concentration was expressed as milligram cyanidin-3-glucoside equivalents using a molar extinction coefficient of 29,600 .

The total phenolic concentration of basil leaves was determined using the modified Folin-Ciocalteu reagent method $(\mathrm{Xu}$ and Mou, 2016) described as follows: a $100-\mu \mathrm{L}$ extraction sample was added to a mixture of $150-\mu \mathrm{L}$ distilled water and $750 \mu \mathrm{L} 1 / 10$ dilution Folin-Ciocalteu reagent; after 6-min reaction, $600 \mu \mathrm{L} 7.5 \% \mathrm{Na}_{2} \mathrm{CO}_{3}$ was added to the mixture. The mixture was incubated at $45^{\circ} \mathrm{C}$ in a water bath for $10 \mathrm{~min}$ before the absorbance was measured at $725 \mathrm{~nm}$ using a microplate reader (ELx800; BioTek, Winooski, VT). Results were expressed as milligram gallic acid equivalent per gram $\mathrm{FW}$ of basil leaves. For total flavonoid concentration, a $20-\mu \mathrm{L}$ extract was mixed with $85 \mu \mathrm{L}$ distilled water and $5 \mu \mathrm{L} 5 \% \mathrm{NaNO}_{2}$. After $6 \mathrm{~min}, 10 \mu \mathrm{L} 10 \% \mathrm{AlCl}_{3} \cdot 6 \mathrm{H}_{2} \mathrm{O}$ was added. After another 5 min, $35 \mu \mathrm{L} 1 \mathrm{M} \mathrm{NaOH}$ and $20 \mu \mathrm{L}$ distilled water was added and then the absorbance was measured at $520 \mathrm{~nm}$ using the microplate reader mentioned previously. The results were expressed as milligram of $(+)$ catechin hydrate equivalent per gram FW of basil leaves. The amounts of total anthocyanin, phenolic compound, and flavonoid per plant were calculated by 
multiplying the concentration of anthocyanin, phenolic compound, and flavonoid by leaf FW per plant.

The total antioxidant capacity of basil leaves was measured using the ferrous ion chelating activity (FICA) method (Xu and Mou, 2016) described as follows: a mixture of $24-\mu \mathrm{L}$ extracts, $1.20 \mathrm{~mL}$ methanol, and $16 \mu \mathrm{L} 2 \mathrm{~mm}$ ferrous chloride were vortexed vigorously. Thirty-two microliters of $5 \mathrm{~mm}$ ferrozine was then added and mixed vigorously, and the absorbance of mixture was measured at $562 \mathrm{~nm}$ after 4-min reaction using the spectrophotometer mentioned previously. The total antioxidant capacity was calculated as the absorbance difference between control $\left(A_{\text {control }}\right)$ and sample $\left(A_{\text {sample }}\right)$ : total antioxidant capacity $(\%$, FICA $)=100 \times$ $\left(A_{\text {control }}-A_{\text {sample }}\right) / A_{\text {control }}$.

Statistical analysis. One-way analysis of variance was conducted to test the effects of DLI on all measured parameters. Mean comparison among treatments was conducted using Student's $t$ method. Correlation test was conducted using the pairwise correlations method. All statistical analyses were performed using JMP (version 13; SAS Institute Inc., Cary, NC).

\section{Results}

Photosynthesis and Chl concentration of basil leaves under different DLIs. The relative Chl concentration per leaf area and SPAD readings increased significantly as basil growth stage developed and DLI increased (Fig. 1A). SPAD for treatments DLI 9.3, DLI 11.5, and DLI 12.9 increased from 30 to 37 after $21 \mathrm{~d}$ of treatment, whereas those in the DLI 16.5 and DLI 17.8 treatments increased to $\approx 41$, which was $11 \%$ higher (Fig. 1A). In contrast, no difference in $\mathrm{Chl}$ a concentration per leaf $\mathrm{FW}$ was observed among the five different DLIs on D21, whereas Chl b concentration was higher for treatments DLI 9.3 and DLI 11.5, and lower for treatments DLI 12.9, DLI 16.5, and DLI 17.8 (Fig. 1B). Higher levels of Chl $\mathrm{a} / \mathrm{b}$ ratio (Fig. 1C) and lower levels of $\mathrm{Chl} \mathrm{a}+\mathrm{b}$ concentration (Fig. 1B) were observed for treatments DLI 12.9, DLI 16.5, and DLI 17.8. The Chl a+b concentration per leaf FW for treatments DLI 9.3 and DLI 11.5 were $\approx 17 \%$ higher than that of basil grown under treatments DLI 12.9, DLI 16.5, and DLI 17.8 (Fig. 1B).

The leaf net photosynthetic rate per leaf area $\left(\mathrm{Pn}_{\text {leaf }}\right)$, transpiration, and $g_{\mathrm{S}}$ of basil leaves increased significantly as DLI increased and were the highest for treatments DLI 12.9, DLI 16.5, and DLI 17.8 (11.5, 10.6, and $\left.10.4 \mu \mathrm{mol} \cdot \mathrm{m}^{-2} \cdot \mathrm{s}^{-1}\right)$, followed by treatments DLI 9.3 and DLI 11.5 (6.1 and 7.8 $\mu \mathrm{mol} \cdot \mathrm{m}^{-2} \cdot \mathrm{s}^{-1}$ ), respectively (Table 1$) . \mathrm{Pn}_{\text {leaf }}$ for treatments DLI 12.9 was $86 \%$ and $47 \%$ higher than that for treatments DLI 9.3 and DLI 11.5, respectively, and no difference among treatments DLI 12.9, DLI 16.5, or DLI 17.8 was observed (Table 1). Transpiration for treatment DLI 12.9 was $78 \%$ and $57 \%$ higher than that for treatments DLI 9.3
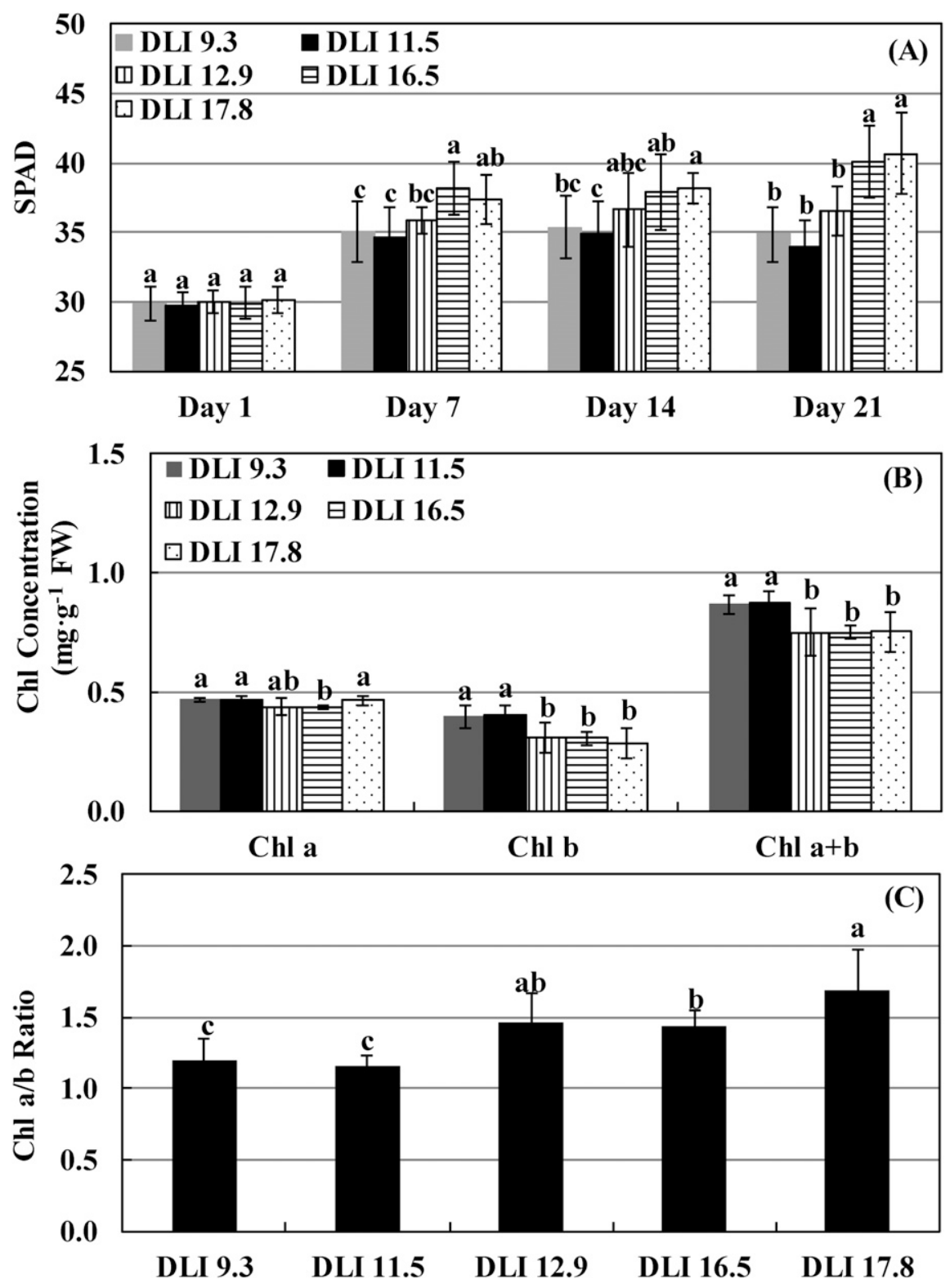

Fig. 1. Relative chlorophyll (Chl) concentration per leaf area (soil plant analysis development) of basil leaves from day 1 to day 21 (A); $\mathrm{Chl} \mathrm{a,} \mathrm{Chl} \mathrm{b,} \mathrm{and} \mathrm{Chl} \mathrm{a}+\mathrm{b}$ concentration per leaf $\mathrm{FW}(\mathbf{B})$; and $\mathrm{Chl}$ $\mathrm{a} / \mathrm{b}$ ratio $(\mathbf{C})$ of 'Improved Genovese Compact' sweet basil grown for $21 \mathrm{~d}$ at different daily light integrals in indoor controlled environment. Means with the same letters within a group are not significantly different according to Student's $t$ mean comparison $(P<0.05)$. FW $=$ fresh weight.

Table 1. Net photosynthetic rate per leaf area, transpiration, substomatal $\mathrm{CO}_{2}$ concentration, and stomatal conductance of 'Improved Genovese Compact' sweet basil leaves grown for $20 \mathrm{~d}$ at different daily light integrals (DLIs) in indoor controlled environment. A portable gas exchange analyzer CIRAS-3 was used to measure the gas exchange rate of basil leaves at the end of the experiment.

\begin{tabular}{lcccc}
\hline Treatment & $\begin{array}{c}\text { Net photosynthetic } \\
\text { rate }\left(\mu \mathrm{mol} \cdot \mathrm{m}^{-2} \cdot \mathrm{s}^{-1}\right)\end{array}$ & $\begin{array}{c}\text { Transpiration } \\
\left(\mathrm{mmol} \cdot \mathrm{m}^{-2} \cdot \mathrm{s}^{-1}\right)\end{array}$ & $\begin{array}{c}\text { Substomatal } \mathrm{CO}_{2} \\
\text { concn }\left(\mu \mathrm{mol} \cdot \mathrm{mol}^{-1}\right)\end{array}$ & $\begin{array}{c}\text { Stomatal conductance } \\
\left(\mathrm{mmol} \cdot \mathrm{m}^{-2} \cdot \mathrm{s}^{-1}\right)\end{array}$ \\
\hline DLI 9.3 & $6.1 \mathrm{c}^{\mathrm{z}}$ & $1.26 \mathrm{c}$ & $266 \mathrm{a}$ & $86 \mathrm{~b}$ \\
DLI 11.5 & $7.8 \mathrm{bc}$ & $1.43 \mathrm{bc}$ & $255 \mathrm{a}$ & $106 \mathrm{~b}$ \\
DLI 12.9 & $11.5 \mathrm{a}$ & $2.24 \mathrm{a}$ & $269 \mathrm{a}$ & $194 \mathrm{a}$ \\
DLI 16.5 & $10.6 \mathrm{a}$ & $2.01 \mathrm{a}$ & $273 \mathrm{a}$ & $172 \mathrm{a}$ \\
DLI 17.8 & $10.4 \mathrm{ab}$ & $1.85 \mathrm{ab}$ & $252 \mathrm{a}$ & $142 \mathrm{ab}$ \\
\hline
\end{tabular}

${ }^{\mathrm{z}}$ Means followed by the same letters are not significantly different within a column, according to Student's $t$ mean comparison $(P<0.05)$.

and DLI 11.5 , whereas $g_{\mathrm{S}}$ for treatments DLI 12.9 was $126 \%$ and $83 \%$ higher than that for treatments DLI 9.3 and DLI 11.5, respectively (Table 1).
Morphological differences of basil influenced by DLIs. Basil plants grown under higher DLIs had a larger canopy because of increased height and widths (Table 2) but had 
Table 2. Plant height and width of 'Improved Genovese Compact' sweet basil on 1, 7, 14, and $21 \mathrm{~d}$ after transplanting at different daily light integrals (DLIs) in indoor controlled environment.

\begin{tabular}{|c|c|c|c|c|c|c|c|c|}
\hline \multirow[b]{2}{*}{ Treatment } & \multicolumn{2}{|c|}{ Day 1} & \multicolumn{2}{|c|}{ Day 7} & \multicolumn{2}{|c|}{ Day 14} & \multicolumn{2}{|c|}{ Day 21} \\
\hline & $\mathrm{Ht}(\mathrm{cm})$ & Width $(\mathrm{cm})$ & $\mathrm{Ht}(\mathrm{cm})$ & Width $(\mathrm{cm})$ & $\mathrm{Ht}(\mathrm{cm})$ & Width $(\mathrm{cm})$ & $\mathrm{Ht}(\mathrm{cm})$ & Width $(\mathrm{cm})$ \\
\hline$\overline{\text { DLI } 9.3}$ & $3.9 \mathrm{a}^{\mathrm{z}}$ & $5.1 \mathrm{a}$ & $5.3 \mathrm{a}$ & $7.7 \mathrm{~b}$ & $10.1 \mathrm{~b}$ & $10.2 \mathrm{~b}$ & $17.4 \mathrm{c}$ & $12.5 \mathrm{~b}$ \\
\hline DLI 11.5 & $3.8 \mathrm{a}$ & $5.4 \mathrm{a}$ & $5.5 \mathrm{a}$ & $7.8 \mathrm{~b}$ & $12.1 \mathrm{a}$ & $10.5 \mathrm{ab}$ & $20.2 \mathrm{~b}$ & $13.0 \mathrm{ab}$ \\
\hline DLI 12.9 & $4.0 \mathrm{a}$ & $5.2 \mathrm{a}$ & $6.1 \mathrm{a}$ & $8.3 \mathrm{ab}$ & $12.7 \mathrm{a}$ & $10.9 \mathrm{a}$ & $22.1 \mathrm{a}$ & $12.8 \mathrm{ab}$ \\
\hline DLI 16.5 & $3.7 \mathrm{a}$ & $4.9 \mathrm{a}$ & $6.0 \mathrm{a}$ & $8.1 \mathrm{ab}$ & $12.9 \mathrm{a}$ & $11.0 \mathrm{a}$ & $23.3 \mathrm{a}$ & $13.0 \mathrm{ab}$ \\
\hline DLI 17.8 & $3.8 \mathrm{a}$ & $5.1 \mathrm{a}$ & $6.3 \mathrm{a}$ & $8.6 \mathrm{a}$ & $13.0 \mathrm{a}$ & $10.8 \mathrm{a}$ & $23.0 \mathrm{a}$ & $13.4 \mathrm{a}$ \\
\hline
\end{tabular}

${ }^{\mathrm{z}}$ Means followed by the same letters are not significantly different within a column, according to Student's $t$ mean comparison $(P<0.05)$.

Table 3. Leaf area per plant, specific leaf area, and first branch height and width of 'Improved Genovese Compact' sweet basil grown for $21 \mathrm{~d}$ at different daily light integrals (DLIs) in indoor controlled environment.

\begin{tabular}{lcccc}
\hline Treatment & Leaf area per plant $\left(\mathrm{cm}^{2} /\right.$ plant $)$ & Specific leaf $\operatorname{area}^{\mathrm{z}}\left(\mathrm{cm}^{2} \cdot \mathrm{g}^{-1}, \mathrm{DW}\right)$ & Ht of first branch $(\mathrm{cm})$ & Width of first branch $(\mathrm{cm})$ \\
\hline DLI 9.3 & $406 \mathrm{~b}^{\mathrm{y}}$ & $518 \mathrm{a}$ & $2.9 \mathrm{c}$ & $3.8 \mathrm{~b}$ \\
DLI 11.5 & $454 \mathrm{~b}$ & $480 \mathrm{ab}$ & $4.5 \mathrm{~b}$ & $5.0 \mathrm{a}$ \\
DLI 12.9 & $560 \mathrm{a}$ & $462 \mathrm{~b}$ & $5.4 \mathrm{ab}$ & $5.7 \mathrm{a}$ \\
DLI 16.5 & $609 \mathrm{a}$ & $389 \mathrm{c}$ & $6.2 \mathrm{a}$ & $5.7 \mathrm{a}$ \\
DLI 17.8 & $614 \mathrm{a}$ & $398 \mathrm{c}$ & $6.3 \mathrm{a}$ & $5.9 \mathrm{a}$ \\
\hline
\end{tabular}

${ }^{\mathrm{z}}$ Specific leaf area $=$ leaf area per unit leaf dry weight (DW).

${ }^{\mathrm{y}}$ Means followed by the same letters are not significantly different within a column, according to Student's $t$ mean comparison $(P<0.05)$.

similar number of internodes (data not presented). The plant widths responded faster to DLIs than plant height, with visible difference after 1-week DLI treatment, whereas it took 2 weeks for plant height to show difference among treatments. On D21, the plant height was the greatest for treatments DLI 12.9, DLI 16.5, and DLI 17.8 (22.1,23.3, and $23.0 \mathrm{~cm}$, respectively), followed by DLI $11.5(20.2 \mathrm{~cm})$, and was the lowest for DLI $9.3(17.4 \mathrm{~cm})$. Although the plant widths showed visual differences earlier than the height, the differences among five DLI treatments were small (Table 2).

Basil plants grown under higher DLIs had larger and thicker leaves, as well as greater branch height and widths (Table 3). With the same number of leaves, the leaf area per plant for treatment DLI 17.8 was $51 \%$ and $35 \%$ higher than that for treatments DLI 9.3 and DLI 11.5, whereas its specific leaf area (leaf area per unit leaf DW) was $30 \%$ and $21 \%$ lower, respectively. Lower specific leaf area under higher DLIs indicated that the thickness of basil leaves increased as DLIs increased. In addition to plant height and widths, the branching of basil was also positively correlated with DLIs. There were two pairs of fully expanded leaves for the first branch of basil plants grown under treatments DLI 12.9, DLI 16.5, and DLI 17.8, whereas only one pair of fully expanded leaves for treatment DLI 9.3 (data not presented), which contributed to increased branch height and widths under higher DLIs (Table 3 ).

Plant growth and yield of basil under different DLIs. The highest shoot FW per plant was observed in treatments DLI 12.9, DLI 16.5, and DLI 17.8 (20.2, 23.4, and $23.3 \mathrm{~g}$, respectively), followed by DLI 11.5 (15.7 g), whereas DLI 9.3 (13.1 g) exhibited the lowest value (Fig. 2A). The fresh leaf and stem weight had the similar trend as fresh shoot yield, whereas the root FW per plant was the highest in treatments DLI 16.5 and DLI 17.8, followed by DLI 12.9 , then DLI 11.5 , and was the lowest in DLI 9.3. The leaf DW per plant was more sensitive to DLIs than leaf
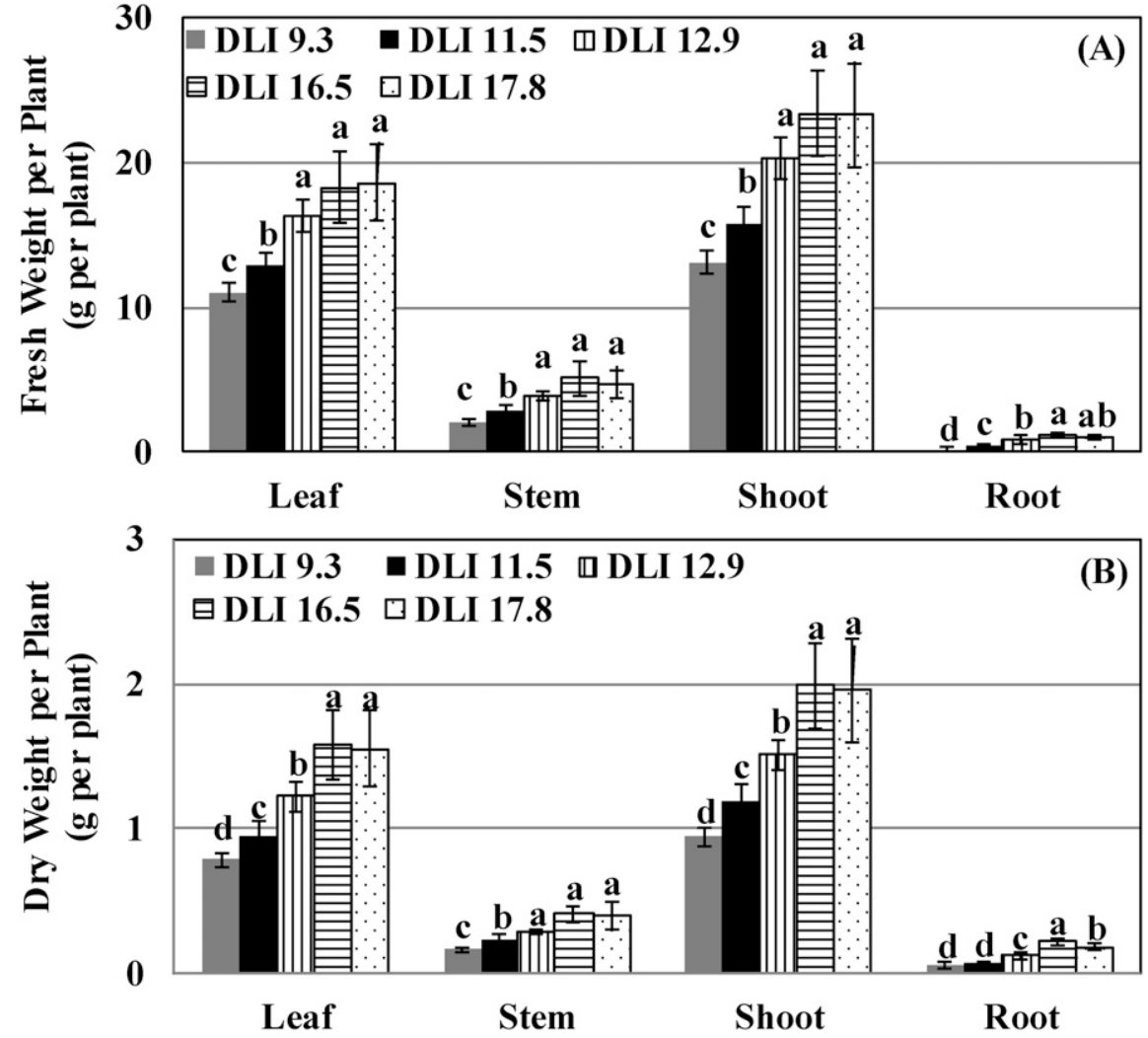

Fig. 2. Leaf, stem, shoot, and root fresh weight (A) per plant and dry weight (B) per plant of 'Improved Genovese Compact' sweet basil grown for $21 \mathrm{~d}$ at different daily light integrals in indoor controlled environment. Means with the same letters within a group are not significantly different according to Student's $t$ mean comparison $(P<0.05)$.

FW, and significant difference was observed among treatments DLI 12.9, DLI 16.5, and DLI 17.8 (1.22, 1.58 , and $1.55 \mathrm{~g}$, respectively) (Fig. 2B). The shoot DW per plant had a similar pattern with leaf DW, whereas shoot DW per plant in DLI 17.8 was more than 2fold than that in DLI 9.3. The shoot FW and DW per plant were both positively correlated with DLIs at the time of harvest on D21, with correlation coefficients of 0.86 and 0.88 , respectively (Fig. 3A). The shoot dry matter percent of basil was also positively influ- enced by DLIs, ranging from $6.7 \%$ to $9.2 \%$ (Fig. 3B).

Nutritional quality of basil leaves under different DLIs. The soluble sugar percent, total phenolic concentration, and total flavonoid concentration of basil leaves increased with DLIs and were $52 \%, 35 \%$, and $85 \%$ higher in treatment DLI 17.8 compared with DLI 9.3, respectively (Table 4). There was no difference for anthocyanin concentration among different DLIs, ranging from 2.60 to $2.82 \mathrm{mg} \cdot 100 \mathrm{~g}^{-1}$ leaf FW (Table 4). The 
increased phenolic compound and flavonoid concentration of basil leaves led to higher antioxidant capacities with increasing DLIs, which was $73 \%$ higher in treatment DLI 17.8 than DLI 9.3 (Table 4). Because of higher leaf FW per plant under higher DLIs, the amounts of total anthocyanin, phenolic, and flavonoid per plant were positively correlated with DLIs with correlation coefficients of $0.84,0.96$, and 0.89 respectively (Fig. 4).

\section{Discussion}

Photosynthetic capacity, Chl concentration, leaf morphology, growth, and yield of sweet basil. As the vital factor affecting plant photosynthesis, DLI or PPFD alters leaf Chl concentration to maximize photosynthetic efficiency and productivity (Retkute et al., 2015; Wittmann et al., 2001). In this study, the $\mathrm{Pn}_{\text {leaf }}$ of sweet basil increased from 6.1 $\mu \mathrm{mol} \cdot \mathrm{m}^{-2} \cdot \mathrm{s}^{-1}$ in treatment DLI 9.3 (relatively low PPFD of $\left.160 \mu \mathrm{mol} \cdot \mathrm{m}^{-2} \cdot \mathrm{s}^{-1}\right)$ to 10.4 $\mu \mathrm{mol} \cdot \mathrm{m}^{-2} \cdot \mathrm{s}^{-1}$ in treatment DLI 17.8 (relatively high PPFD of $310 \mu \mathrm{mol} \cdot \mathrm{m}^{-2} \cdot \mathrm{s}^{-1}$ ) (Table 1), inferring that the light saturation point of sweet basil is higher than 310 $\mu \mathrm{mol} \cdot \mathrm{m}^{-2} \cdot \mathrm{s}^{-1}$ under this environment. Similarly, Polyakova et al. (2015) reported that the $\mathrm{Pn}_{\text {leaf }}$ of 'Ararat' basil grown for $30 \mathrm{~d}$
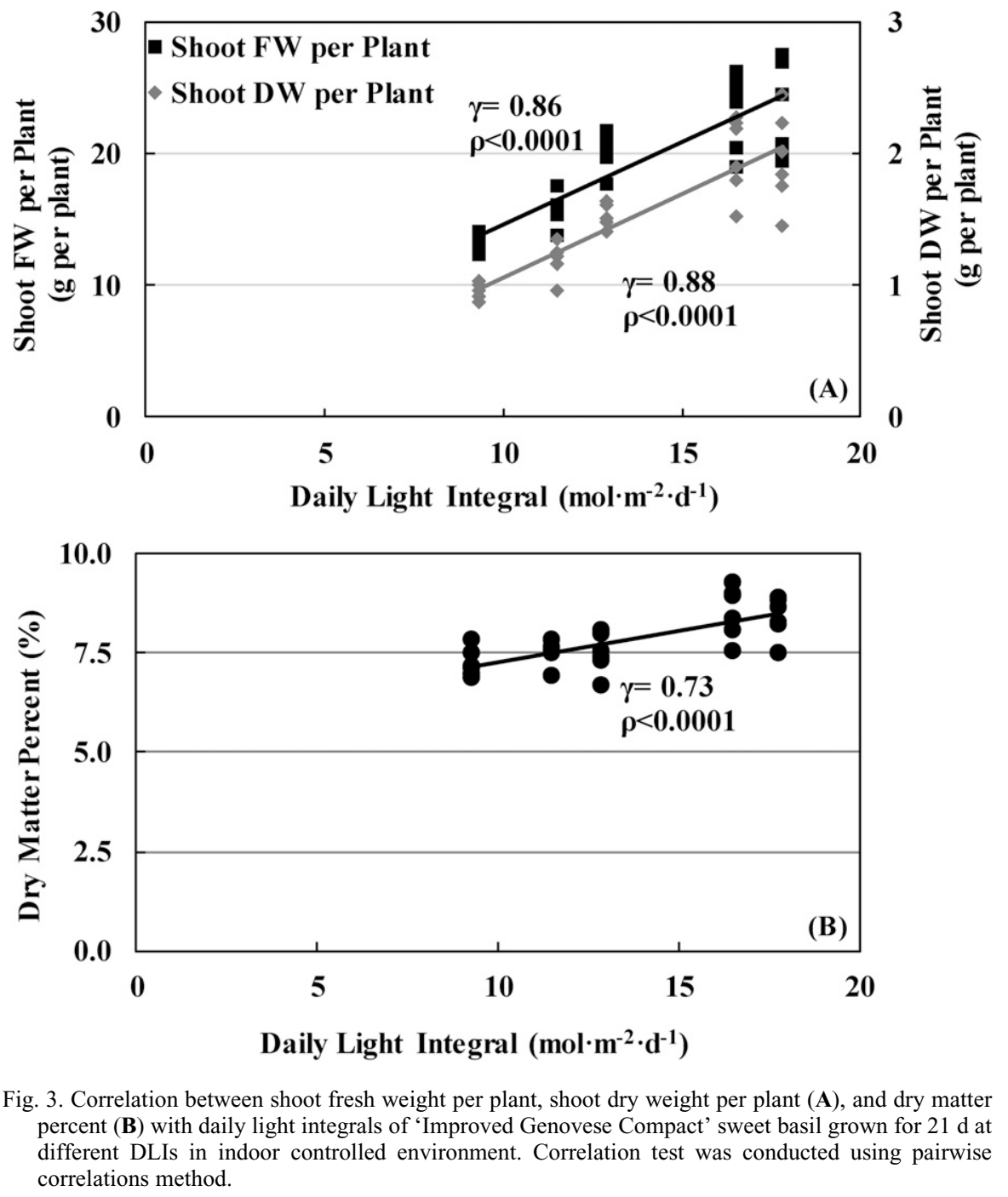

Daily Light Integral $\left(\mathrm{mol} \cdot \mathrm{m}^{-2} \cdot \mathrm{d}^{-1}\right)$

Fig. 3. Correlation between shoot fresh weight per plant, shoot dry weight per plant (A), and dry matter percent (B) with daily light integrals of 'Improved Genovese Compact' sweet basil grown for $21 \mathrm{~d}$ at different DLIs in indoor controlled environment. Correlation test was conducted using pairwise correlations method.

under $240-260 \mu \mathrm{mol} \cdot \mathrm{m}^{-2} \cdot \mathrm{s}^{-1}$ provided by induction lamps was more than twice higher than that of plants grown under 80-85 $\mu \mathrm{mol} \cdot \mathrm{m}^{-2} \cdot \mathrm{s}^{-1}$ provided by white LEDs. One reason for the increased $\mathrm{Pn}_{\text {leaf }}$ of high-light leaves is their generally higher Chl concentration per leaf area (Lichtenthaler et al., 2007). $\mathrm{Pn}_{\text {leaf }}$ represents the sum of individual cell $\mathrm{CO}_{2}$ assimilation, and the thinner leaves under lower DLIs contain significantly less cells per leaf area as compared with thicker leaves under higher DLIs (Table 3), which consequently resulted in lower $\mathrm{Chl}$ concentration per leaf area (SPAD) and $\mathrm{Pn}_{\text {leaf }}$ (Fig. 1A; Table 1). SPAD reading of plants was mainly associated with a greater amount of nitrogen per leaf area, as well as higher concentration of RuBisCo enzyme, and subsequently resulted in increased photosynthesis (Lichtenthaler, 1985). Increased SPAD reading also led to darker green leaves of basil plants under higher DLIs, which play an important role for consumers making purchasing decisions (Rouphael et al., 2012). Basil plants under higher DLIs exhibited higher Pn not only on leaf area basis but also on Chl basis and leaf DW basis (Fig. 5), which could be explained by the possession of chloroplasts adapted to higher PPFD under higher DLIs. The high-light-adapted chloroplasts had higher photosynthetic quantum conversion rate with adapted ultrastructure, biochemical organization and a special arrangement of Chls, and carotenoids in the thylakoids under higher DLIs, resulting in increased Pn on Chl basis and leaf DW basis (Lichtenthaler et al., 2007).

In contrast to Chl concentration on leaf area basis, basil leaves under lower DLIs had a significantly higher $\mathrm{Chl} \mathrm{a}+\mathrm{b}$ concentration per leaf FW, and treatment DLI 9.3 was up to $16 \%$ higher than treatment DLI 17.8 (Fig. 1B). This result was consistent with the $\mathrm{Chl} \mathrm{a}+\mathrm{b}$ concentration of 'Ararat' basil and Glycyrrhiza uralensis grown under different DLIs (Hou et al., 2010; Polyakova et al., 2015). The increased $\mathrm{Chl} \mathrm{a}+\mathrm{b}$ concentrations of basil leaves under lower DLIs resulted from increased $\mathrm{Chl} b$ concentration with similar Chl a concentration and consequently lower $\mathrm{Chl} \mathrm{a} / \mathrm{b}$ ratios (Fig. $1 \mathrm{C}$ ). The difference in $\mathrm{Chl} \mathrm{a} / \mathrm{b}$ ratios is also a useful indicator of light conditions, with lower $\mathrm{Chl}$ $\mathrm{a} / \mathrm{b}$ ratios in shade leaves and higher $\mathrm{Chl}$ $\mathrm{a} / \mathrm{b}$ ratios in sun leaves (Sarijeva et al., 2007). Under lower DLIs, plants maximize lightharvesting capacity by increasing light-harvesting Chl-protein complex in photosystem II, which

Table 4. Brix, anthocyanin concentration, total phenolic concentration (gallic acid equivalent, GAE), total flavonoid concentration $[(+)$-catechin hydrate equivalent, $\mathrm{CHE}$ ], and antioxidant capacity (ferrous ion chelating activity, FICA) of 'Improved Genovese Compact' sweet basil leaves grown for $21 \mathrm{~d}$ at different daily light integrals (DLIs) in indoor controlled environment.

\begin{tabular}{|c|c|c|c|c|c|}
\hline Treatment & Brix $(\%)$ & $\begin{array}{l}\text { Anthocyanin concn } \\
\left(\mathrm{mg} \cdot 100 \mathrm{~g}^{-1} \mathrm{FW}\right)\end{array}$ & $\begin{array}{l}\text { Total phenolic concn } \\
\left(\mathrm{GAE} \mathrm{mg} \cdot \mathrm{g}^{-1} \mathrm{FW}\right)\end{array}$ & $\begin{array}{l}\text { Total flavonoid concn } \\
\left(\mathrm{CHE} \mathrm{mg} \cdot \mathrm{g}^{-1} \mathrm{FW}\right)\end{array}$ & $\begin{array}{c}\text { Antioxidant capacity } \\
(\%, \text { FICA })\end{array}$ \\
\hline DLI 9.3 & $2.3 \mathrm{c}^{\mathrm{z}}$ & $2.60 \mathrm{a}$ & $1.02 \mathrm{~b}$ & $0.34 \mathrm{c}$ & $1.96 \mathrm{~b}$ \\
\hline DLI 11.5 & $2.7 \mathrm{bc}$ & $2.76 \mathrm{a}$ & $1.07 \mathrm{~b}$ & $0.47 \mathrm{~b}$ & $3.46 \mathrm{ab}$ \\
\hline DLI 12.9 & $2.9 \mathrm{~b}$ & $2.82 \mathrm{a}$ & $0.99 \mathrm{~b}$ & $0.40 \mathrm{bc}$ & $3.80 \mathrm{ab}$ \\
\hline DLI 16.5 & $2.5 \mathrm{bc}$ & $2.82 \mathrm{a}$ & $1.61 \mathrm{a}$ & $0.90 \mathrm{a}$ & $5.26 \mathrm{a}$ \\
\hline DLI 17.8 & $3.5 \mathrm{a}$ & $2.73 \mathrm{a}$ & $1.38 \mathrm{a}$ & $0.63 \mathrm{a}$ & $3.37 \mathrm{ab}$ \\
\hline
\end{tabular}

${ }^{\mathrm{z}}$ Means followed by the same letters are not significantly different within a column, according to Student's $t$ mean comparison $(P<0.05)$.

$\mathrm{FW}=$ fresh weight. 

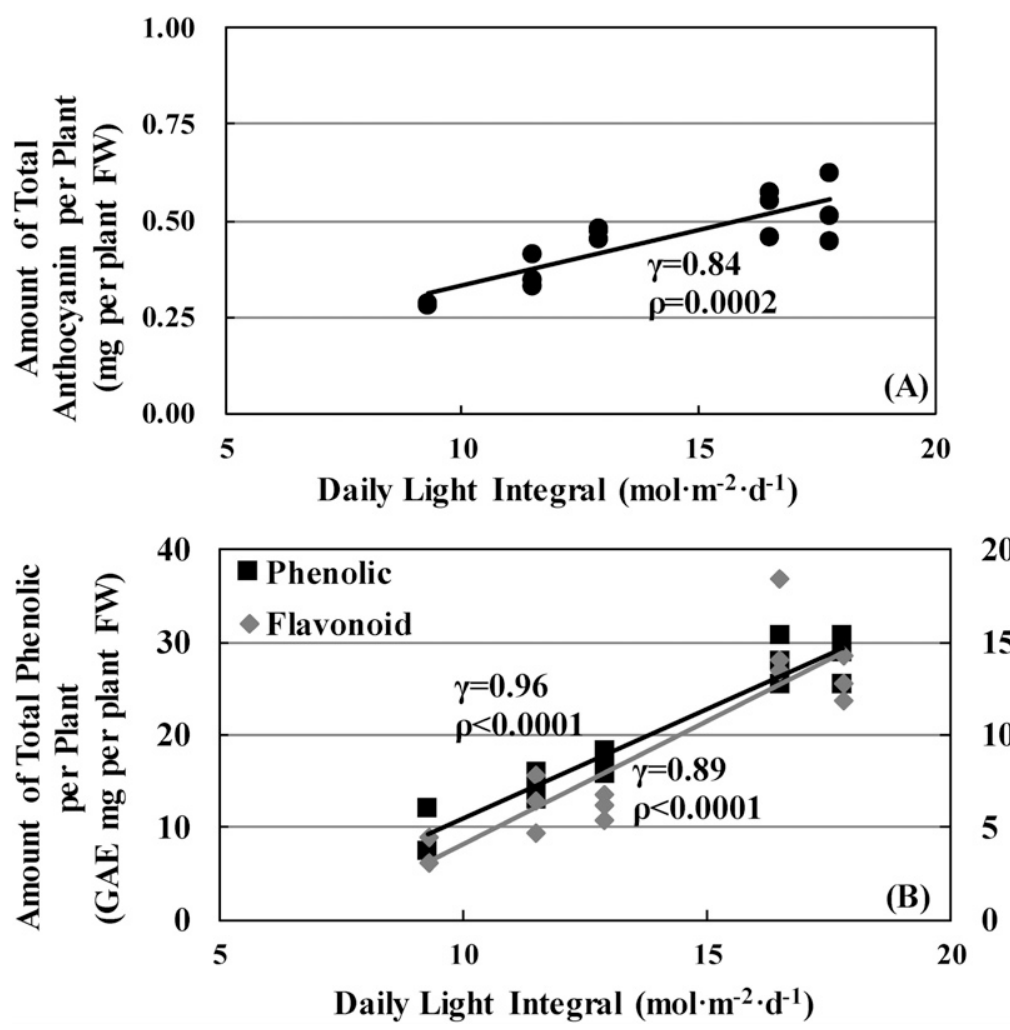

Fig. 4. Correlation between amount of total anthocyanin per plant (A), amount of total phenolic per plant (gallic acid equivalent), and amount of total flavonoid per plant $[(+)$-catechin hydrate equivalent] (B) with daily light integral of 'Improved Genovese Compact' sweet basil grown for $21 \mathrm{~d}$ at different DLIs in indoor controlled environment. Correlation test was conducted using pairwise correlations method.

contains most of the $\mathrm{Chl} \mathrm{b}$, and consequently a higher $\mathrm{Chl} \mathrm{b}$ concentration and lower $\mathrm{Chl} \mathrm{a/}$ b ratio (Kitajima and Hogan, 2003; Sarijeva et al., 2007). The increased Chl a+b concentration per leaf FW under lower DLIs demonstrated the plants' ability to maximize the light-harvesting capacity under lower light conditions (Dai et al., 2009). Accordingly, $\mathrm{Chl} \mathrm{a}+\mathrm{b}$ concentration was correlated with $\mathrm{Chl}$ a/b ratio negatively and $\mathrm{Pn}_{\text {leaf }}$ positively (Fig. 6).

Plant photosynthetic rate per leaf area depends not only on photosynthetic biochemistry but also on the mesophyll structure of leaves (Retkute et al., 2015). Because resistance to $\mathrm{CO}_{2}$ diffusion from the substomatal cavity to the stroma is substantial, the mesophyll structure affects $\mathrm{Pn}_{\text {leaf }}$ by affecting the diffusion of $\mathrm{CO}_{2}$ (Terashima et al., 2001) and the penetration of light in leaves (Vogelmann and Martin, 1993). The increased $g_{\mathrm{S}}$ under higher DLIs indicated that basil leaves were able to open their stomata much wider under higher DLIs, which increased the leaf transpiration accordingly (Table 1). This certainly appears to be an essential prerequisite for increased $\mathrm{Pn}_{\text {leaf }}$ under higher DLIs (Table 1; Fig. 5).

Basil leaves developed in lower DLIs are thinner and smaller than those growing in higher DLIs (Table 3), which reduced the respiratory cost of basil leaves to help compensating for the greatly decreased photosynthetic capacity (Dai et al., 2009). Meanwhile, the mesophyll cells of basil leaves under higher DLIs are more compact (associated with higher dry matter percent) compared with lower DLIs (Fig. 3B). Under lower DLIs, decreased $\mathrm{Pn}_{\text {leaf }}$ produced insufficient ATPs with low carbon fixation and carbohydrate biosynthesis, resulting in smaller plant canopy (Table 2) and decreased shoot and root FW/DW per plant (Fig. 2). Accordingly, the shortage of photo-assimilate supplies and inadequate sucrose synthesis led to a reduction in soluble sugar percent (Table 4) compared with plants grown under higher DLIs.

Effects of DLIS on the synthesis of anthocyanin, phenolics, and flavonoids in sweet basil. Plant leaves adapt to light conditions not only anatomically and morphologically, but also biochemically. In addition to stimulating photosynthetic pigments, high DLIs also stimulate the biosynthesis and accumulation of nonphotosynthetic pigments and antioxidants, e.g., anthocyanins, phenolics, and flavonoids (Albert et al., 2009; Bian et al., 2015; Cominelli et al., 2008; Dou et al., 2017; Wu et al., 2007), acting as screens to reduce the excess light received by photosynthetic apparatuses (Logan et al., 2015).

Synthesis of phenolic compounds, including phenolic acids, flavonoids, and anthocyanins, is enhanced under strong ultraviolet and visible light conditions (Takahashi and Badger, 2011; Winkel-Shirley, 2002). Across a range of plant species, phenolic compounds act as light attenuators, act as light-screening agents, and play photoprotective roles, which are supported by a large body of experimental evidences (Agati and Tattini, 2010; Akula and Ravishankar, 2011; Gould et al., 2010; Hatier et al., 2013; Solovchenko, 2010). For example, purple basil 'Red Rubin' had lower metabolic cost of photoprotective mechanisms and higher biomass increase than green basil 'Tigullio' when being moved from 30\% to $100 \%$ sunlight, which means purple basil with more anthocyanins was more tolerant of higher DLIs than green basil (Tattini et al., 2014). Corroborating existing empirical studies and theoretical predictions, the amount of total anthocyanin per plant of sweet basil was positively influenced by DLIs with a correlation coefficient of 0.84 (Fig. 4A). It is also reported that flavonoids play a more important role than xanthophylls in protecting Arabidopsis leaves from long-term visible light-induced oxidative damage (Havaux and Kloppstech, 2001). The concentration of total phenolic and flavonoid of basil leaves were both enhanced under higher DLIs (Table 4), and the amounts of total phenolic and flavonoid per plant were positively correlated with DLIs (Fig. 4B). Similarly, Mitchell petunia [Petunia axillaris $\times(P$. axillaris $\times$ Petunia hybrida cv. Rose of Heaven)] plants displayed intense anthocyanin concentration throughout the leaves and stems when grown under $750 \mu \mathrm{mol} \cdot \mathrm{m}^{-2} \cdot \mathrm{s}^{-1}$ compared with 50 $350 \mu \mathrm{mol} \cdot \mathrm{m}^{-2} \cdot \mathrm{s}^{-1}$, as well as the activation of the early and late flavonoid biosynthetic genes required for flavonoids and anthocyanin production (Albert et al., 2009). The enrichment of potent antioxidants, namely, anthocyanins, phenolics, and flavonoids resulted in higher antioxidant capacity of basil leaves grown under higher DLIs (Table 4).

Future research perspectives. This experiment was conducted at five DLIs created by growing basil plants under five different PPFD with the same 16-h photoperiod. As one factor of the lighting conditions, photoperiod also influences leaf expansion, crop yield, and nutritional content accumulation of plants (Beaman et al., 2009). Few studies on responses of basil plants to different photoperiods in indoor controlled environment were published because it is believed that basil is a long-day plant, and a 16-h photoperiod was used in most studies on basil controlled-environment cultivation with artificial lighting (Beaman et al., 2009; Piovene et al., 2015). However, what is the response of basil plants to DLIs created by different photoperiods with the same PPFD? Furthermore, what is the response of basil plants to different combinations of PPFD and photoperiod at the same optimal DLI? These might be the future research perspectives.

\section{Conclusions}

Under indoor controlled environment, basil plants grown under higher DLIs had increased photosynthetic capacity per unit leaf area, Chl concentration, leaf DW per plant, and higher $\mathrm{Chl} \mathrm{a} / \mathrm{b}$ ratios. The higher photosynthetic capacity resulted in larger canopy and branching, larger and thicker 

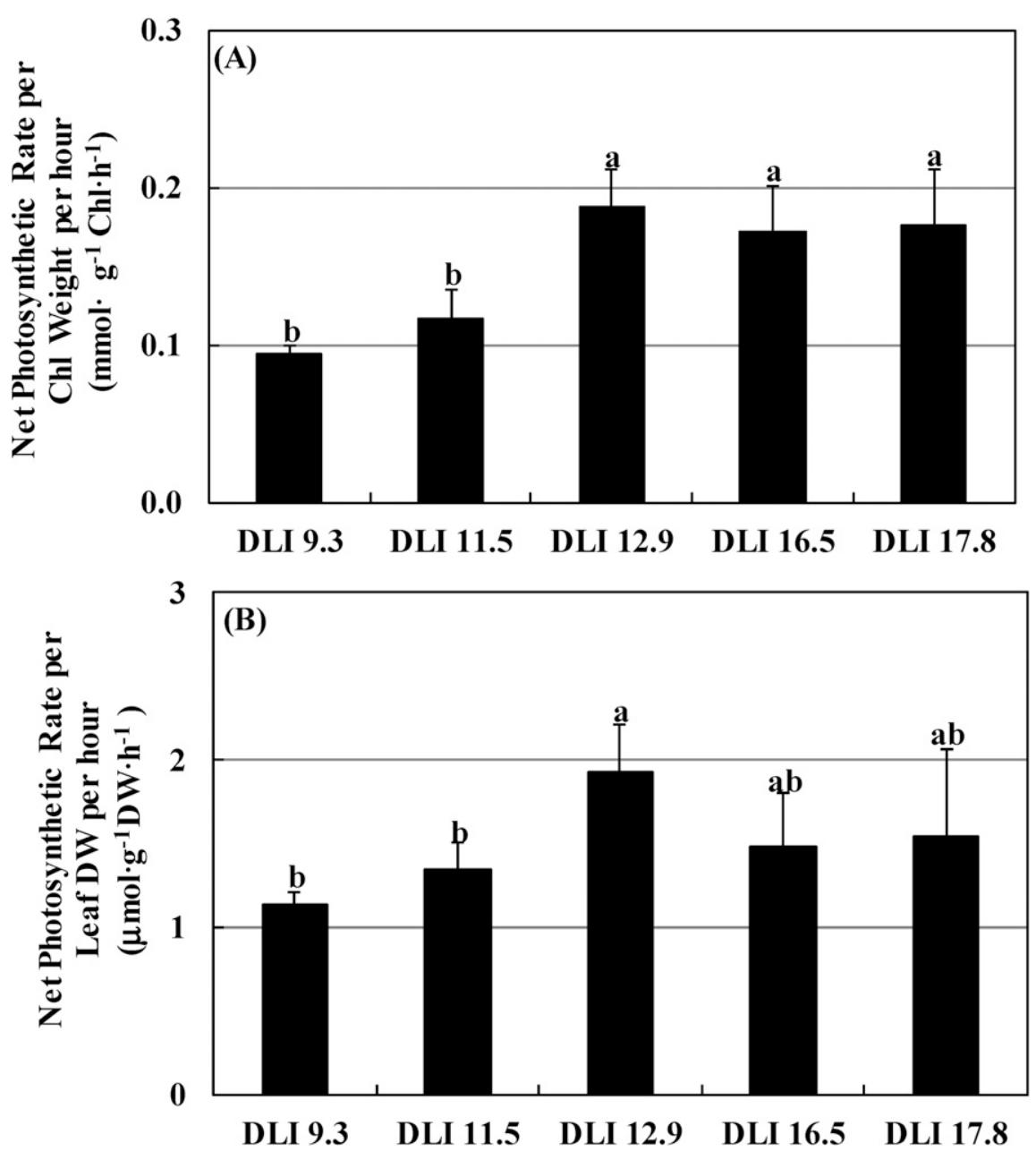

Fig. 5. Net photosynthetic rate per chlorophyll weight per hour (A) and net photosynthetic rate per leaf dry weight per hour (B) of 'Improved Genovese Compact' sweet basil grown for $21 \mathrm{~d}$ at different daily light integrals in indoor controlled environment. Means with the same letters are not significantly different according to Student's $t$ mean comparison $(P<0.05)$.

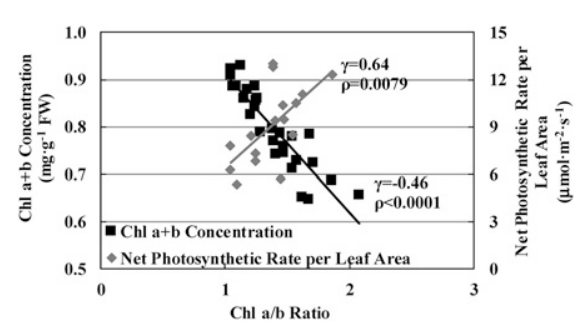

Fig. 6. Correlation of chlorophyll (Chl) $\mathrm{a}+\mathrm{b}$ concentration with $\mathrm{Chl} \mathrm{a} / \mathrm{b}$ ratio and net photosynthetic rate per leaf area with $\mathrm{Chl} \mathrm{a} / \mathrm{b}$ ratio of 'Improved Genovese Compact' sweet basil grown for $21 \mathrm{~d}$ at different daily light integrals in indoor controlled environment. Correlation test was conducted using pairwise correlations method.

leaves, greater leaf and shoot yield, and higher dry matter percent under DLIs of $12.9,16.5$, and $17.8 \mathrm{~mol} \cdot \mathrm{m}^{-2} \cdot \mathrm{d}^{-1}$, compared with 9.3 and $11.5 \mathrm{~mol} \cdot \mathrm{m}^{-2} \cdot \mathrm{d}^{-1}$. Meanwhile, the soluble sugar percent and amounts of total anthocyanin, phenolic compounds, and flavonoids per plant were positively correlated with DLIs, and the antioxidant capacity of basil leaves at a DLI of $17.8 \mathrm{~mol} \cdot \mathrm{m}^{-2} \cdot \mathrm{d}^{-1}$ was
Beaman, A.R., R.J. Gladon, and J.A. Schrader. 2009. Sweet basil requires an irradiance of 500 $\mu \mathrm{mol} \cdot \mathrm{m}^{-2} \cdot \mathrm{s}^{-1}$ for greatest edible biomass production. HortScience 44:64-67.

Bian, Z.H., Q.C. Yang, and W.K. Liu. 2015. Effects of light quality on the accumulation of phytochemicals in vegetables produced in controlled environments: A review. J. Sci. Food Agr. 95:869-877.

Bochenek, G.M. and I. Fallstrom. 2016. The effect of diurnal light intensity distribution on plant productivity in a controlled environment. In: C.J. Currey, R.G. Lopez, and E.S. Runkle (eds.). Proc. VIII Intl. Symp. Light Hort. 1134:155-162.

Chang, X., P.G. Alderson, and C.J. Wright. 2008. Solar irradiance level alters the growth of basil (Ocimum basilicum L.) and its content of volatile oils. Environ. Expt. Bot. 63:216-223.

Chiang, L.C., L.T. Ng, P.W. Cheng, W. Chiang, and C.C. Lin. 2005. Antiviral activities of extracts and selected pure constituents of Ocimum basilicum. Clin. Expt. Pharmacol. Physiol. 32:811-816.

Colonna, E., Y. Rouphael, G. Barbieri, and S. De Pascale. 2016. Nutritional quality of ten leafy vegetables harvested at two light intensities. Food Chem. 199:702-710.

Cominelli, E., G. Gusmaroli, D. Allegra, M. Galbiati, H.K. Wade, G.I. Jenkins, and C. Tonelli. 2008. Expression analysis of anthocyanin regulatory genes in response to different light qualities in Arabidopsis thaliana. J. Plant Physiol. 165:886-894.

Dai, Y., Z. Shen, Y. Liu, L. Wang, D. Hannaway, and H. Lu. 2009. Effects of shade treatments on the photosynthetic capacity, chlorophyll fluorescence, and chlorophyll content of Tetrastigma hemsleyanum Diels et Gilg. Environ. Expt. Bot. 65:177-182.

Department of Agriculture, Forestry and Fisheries of Republic of South Africa. 2012. Basil production. Dept. Agr. For. Fish, Republic of South Africa.

Despommier, D. 2010. The vertical farm: Feeding the world in the 21st century. Macmillan, New York, NY.

Despommier, D. 2013. Farming up the city: The rise of urban vertical farms. Trends Biotechnol. 31:388-389.

$73 \%$ higher than $9.3 \mathrm{~mol} \cdot \mathrm{m}^{-2} \cdot \mathrm{d}^{-1}$. Combining results in growth, yield, and nutritional quality of sweet basil, we suggest a DLI of 12.9 $\mathrm{mol} \cdot \mathrm{m}^{-2} \cdot \mathrm{d}^{-1}$ for basil commercial production in indoor vertical farming to minimize the energy cost while maintaining a high yield and nutritional quality.

\section{Literature Cited}

Aerofarms. 2017. US (NJ): IKEA \& top chef David Chang round out financing for AeroFarms. Hortidaily. 11 Nov. 2017. <http://www. horidaily.com/article/38763/US-(NJ)-IKEA$\&$-top-chef-David-Chang-round-out-financingfor-AeroFarms>.

Agati, G. and M. Tattini. 2010. Multiple functional roles of flavonoids in photoprotection. New Phytol. 186:786-793.

Akula, R. and G.A. Ravishankar. 2011. Influence of abiotic stress signals on secondary metabolites in plants. Plant Signal. Behav. 6:17201731.

Albert, N.W., D.H. Lewis, H. Zhang, L.J. Irving, P.E. Jameson, and K.M. Davies. 2009. Lightinduced vegetative anthocyanin pigmentation in Petunia. J. Expt. Bot. 60:2191-2202.

Albright, L., A.J. Both, and A. Chiu. 2000. Controlling greenhouse light to a consistent daily integral. Trans. Amer. Soc. Agr. Eng. 43:421431.

Dou, H., G. Niu, M. Gu, and J.G. Masabni. 2017. Effects of light quality on growth and phytonutrient accumulation of herbs under controlled environments. Horticulturae 3:36.

Dunwoody, R.K. 2014. Aquaponics and hydroponics: The effects of nutrient source and hydroponic subsystem design on sweet basil production. Univ. Ctr. Misso., Warrensburg, MS Diss. Abstr.

Figueiredo, A.C., J.G. Barroso, L.G. Pedro, and J.J. Scheffer. 2008. Factors affecting secondary metabolite production in plants: Volatile components and essential oils. Flav. Frag. J. 23:213-226.

Fischer, R., N. Nitzan, D. Chaimovitsh, B. Rubin, and N. Dudai. 2011. Variation in essential oil composition within individual leaves of sweet basil (Ocimum basilicum L.) is more affected by leaf position than by leaf age. J. Agr. Food Chem. 59:4913-4922.

Gould, K.S., D.A. Dudle, and H.S. Neufeld. 2010. Why some stems are red: Cauline anthocyanins shield photosystem II against high light stress. J. Expt. Bot. 61:2707-2717.

Hassanpouraghdam, M.B., G.R. Gohari, S.J. Tabatabaei, and M.R. Dadpour. 2010. Inflorescence and leaves essential oil composition of hydroponically grown Ocimum basilicum L. J. Serbian Chem. Soc. 75:1361-1368. 
Hatier, J.H.B., M.J. Clearwater, and K.S. Gould. 2013. The functional significance of blackpigmented leaves: Photosynthesis, photoprotection and productivity in Ophiopogon planiscapus 'Nigrescens'. PLoS One 8(6):e67850.

Havaux, M. and K. Kloppstech. 2001. The protective functions of carotenoid and flavonoid pigments against excess visible radiation at chilling temperature investigated in Arabidopsis NPQ and TT mutants. Planta 213:953-966.

Hou, J.L., W.D. Li, Q.Y. Zheng, W.Q. Wang, B. Xiao, and D. Xing. 2010. Effect of low light intensity on growth and accumulation of secondary metabolites in roots of Glycyrrhiza uralensis Fisch. Biochem. Syst. Ecol. 38:160 168.

Kiferle, C., M. Lucchesini, A. Mensuali-Sodi, R. Maggini, A. Raffaelli, and A. Pardossi. 2011. Rosmarinic acid content in basil plants grown in vitro and in hydroponics. Ctr. Eur. J. Biol. 6:946-957.

Kitajima, K. and K. Hogan. 2003. Increases of chlorophyll $\mathrm{a} / \mathrm{b}$ ratios during acclimation of tropical woody seedlings to nitrogen limitation and high light. Plant Cell Environ. 26:857-865.

Kozai, T. 2007. Propagation, grafting and transplant production in closed systems with artificial lighting for commercialization in Japan. Prop. Ornam. Plants 7:145-149.

Kozai, T. 2013. Resource use efficiency of closed plant production system with artificial light: Concept, estimation and application to plant factory. Proc. Jpn. Acad. Ser. B Phys. Biol. Sci. 89:447.

Kozai, T., G. Niu, and M. Takagaki. 2015. Plant factory: An indoor vertical farming system for efficient quality food production. Academic Press, San Diego, CA.

Kruma, Z., M. Andjelkovic, R. Verhe, V. Kreicbergs, D. Karklina, and P. Venskutonis. 2008. Phenolic compounds in basil, oregano and thyme. Foodbalt 5:99-103.

Liaros, S., K. Botsis, and G. Xydis. 2016. Technoeconomic evaluation of urban plant factories: The case of basil (Ocimum basilicum). Sci. Total Environ. 554:218-227.

Lichtenthaler, H.K. 1985. Differences in morphology and chemical composition of leaves grown at different light intensities and qualities. Control Leaf Growth 1985:201-221.

Lichtenthaler, H.K., A. Ač, M.V. Marek, J. Kalina, and O. Urban. 2007. Differences in pigment composition, photosynthetic rates and chlorophyll fluorescence images of sun and shade leaves of four tree species. Plant Physiol. Biochem. 45:577-588.

Logan, B.A., W.C. Stafstrom, M.J. Walsh, J.S. Reblin, and K.S. Gould. 2015. Examining the photoprotection hypothesis for adaxial foliar anthocyanin accumulation by revisiting comparisons of green-and red-leafed varieties of coleus (Solenostemon scutellarioides). Photosyn. Res. 124:267-274.

Makri, O. and S. Kintzios. 2008. Ocimum sp. (basil): Botany, cultivation, pharmaceutical properties, and biotechnology. J. Herbs Spices Med. Plants 13:123-150.

Nitz, G.M. and W.H. Schnitzler. 2004. Effect of PAR and UV-B radiation on the quality and quantity of the essential oil in sweet basil (Ocimum basilicum L.). In: D.J. Cantliffe, P.J. Stoffella, and N.L. Shaw (eds.). Proc. VII Intl. Symp. Protected Cult. Mild Winter Climates: Prod. Pest Mgt. Global Comp. 1:375-381.

Ohyama, K., T. Kozai, C. Kubota, C. Chun, T. Hasegawa, S. Yokoi, and M. Nishimura. 2002 Coefficient of performance for cooling of a home-use air conditioner installed in a closedtype transplant production system (in Japanese). J. Soc. High Technol. Agr. 14:141-146.

Ohyama, K., K. Manabe, Y. Omura, C. Kubota, and T. Kozai. 2003. A comparison between closed-type and opend-type transplant production systems with respect to quality of tomato (Lycopersicon esculentum) plug transplants and resource consumption during summer (in Japanese). Environ. Control Biol. 41:57-61.

Park, K.S., K. Bekhzod, J.K. Kwon, and J.E. Son 2016. Development of a coupled photosynthetic model of sweet basil hydroponically grown in plant factories. Hort. Environ. Biotechnol. 57:20-26.

Piovene, C., F. Orsini, S. Bosi, R. Sanoubar, V. Bregola, G. Dinelli, and G. Gianquinto. 2015. Optimal red: Blue ratio in LED lighting for nutraceutical indoor horticulture. Scientia Hort. 193:202-208.

Polyakova, M., T.M. Yu, T. Dilovarova, and A. Kosobryukhov. 2015. Photosynthesis and productivity of basil plants (Ocimum basilicum L.) under different irradiation. Agr. Biol. 50 (1):124-130.

Porra, R., W. Thompson, and P. Kriedemann. 1989. Determination of accurate extinction coefficients and simultaneous equations for assaying chlorophylls a and b extracted with four different solvents: Verification of the concentration of chlorophyll standards by atomic absorption spectroscopy. Biochim. Biophys. Acta 975:384-394.

Pushpangadan, P. and V. George. 2012. Basil, p. 55-72. In: K.V. Peter (ed.). Handbook of herbs and spices. Elsevier, Atlanta, GA.

Retkute, R., S.E. Smith-Unna, R.W. Smith, A.J. Burgess, O.E. Jensen, G.N. Johnson, S.P. Preston, and E.H. Murchie. 2015. Exploiting heterogeneous environments: Does photosynthetic acclimation optimize carbon gain in fluctuating light? J. Expt. Bot. 66:2437-2447.

Rouphael, Y., M. Cardarelli, A. Bassal, C. Leonardi, F. Giuffrida, and G. Colla. 2012. Vegetable quality as affected by genetic, agronomic and environmental factors. J. Food Agr. Environ. 10:680-688.

Saha, S., A. Monroe, and M.R. Day. 2016. Growth, yield, plant quality and nutrition of basil (Ocimum basilicum L.) under soilless agricultural systems. Ann. Agr. Sci. 61:181-186.

Sarijeva, G., M. Knapp, and H.K. Lichtenthaler. 2007. Differences in photosynthetic activity, chlorophyll and carotenoid levels, and in chlorophyll fluorescence parameters in green sun and shade leaves of Ginkgo and Fagus. J. Plant Physiol. 164:950-955.

Sgherri, C., S. Cecconami, C. Pinzino, F. NavariIzzo, and R. Izzo. 2010. Levels of antioxidants and nutraceuticals in basil grown in hydroponics and soil. Food Chem. 123:416-422.

Shafiee-Hajiabad, M., J. Novak, and B. Honermeier. 2016. Content and composition of essential oil of four Origanum vulgare L. accessions under reduced and normal light intensity conditions. J. Appl. Bot. Food Qual. 89:126-134.

Solovchenko, A. 2010. Localization of screening pigments within plant cells and tissues, p. $67-$ 88. In: Photoprotection in plants. Springer, New York, NY

Takahashi, S. and M.R. Badger. 2011. Photoprotection in plants: A new light on photosystem II damage. Trends Plant Sci. 16:53-60.

Tattini, M., M. Landi, C. Brunetti, C. Giordano, D. Remorini, K.S. Gould, and L. Guidi. 2014. Epidermal coumaroyl anthocyanins protect sweet basil against excess light stress: Multiple consequences of light attenuation. Physiol. Plant. 152:585-598.

Terashima, I., S.I. Miyazawa, and Y.T. Hanba 2001. Why are sun leaves thicker than shade leaves?-Consideration based on analyses of $\mathrm{CO}_{2}$ diffusion in the leaf. J. Plant Res. 114:93-105.

Touliatos, D., I.C. Dodd, and M. Mcainsh. 2016. Vertical farming increases lettuce yield per unit area compared to conventional horizontal hydroponics. Food Energy Secur. 5:184-191.

Vogelmann, T. and G. Martin. 1993. The functional significance of palisade tissue: Penetration of directional versus diffuse light. Plant Cell Environ. 16:65-72.

Walters, K.J. and C.J. Currey. 2015. Hydroponic greenhouse basil production: Comparing systems and cultivars. HortTechnology 25:645-650.

Winkel-Shirley, B. 2002. Biosynthesis of flavonoids and effects of stress. Curr. Opin. Plant Biol. 5:218-223.

Wittmann, C., G. Aschan, and H. Pfanz. 2001. Leaf and twig photosynthesis of young beech (Fagus sylvatica) and aspen (Populus tremula) trees grown under different light regime. Basic Appl. Ecol. 2:145-154.

Wu, M.C., C.Y. Hou, C.M. Jiang, Y.T. Wang, C.Y. Wang, H.H. Chen, and H.M. Chang. 2007. A novel approach of LED light radiation improves the antioxidant activity of pea seedlings. Food Chem. 101:1753-1758.

$\mathrm{Xu}$, C.P. and B.Q. Mou. 2016. Responses of spinach to salinity and nutrient deficiency in growth, physiology, and nutritional value. J. Amer. Soc. Hort. Sci. 141:12-21.

Yokoi, S., T. Kozai, T. Hasegawa, C. Chun, and C. Kubota. 2005. $\mathrm{CO}_{2}$ and water utilization efficiencies of a closed transplant production system as affected by leaf area index of tomato seedling populations and the number of air exchanges. J. Soc. High Technol. Agr. 18:182181. 